\title{
Germinação e propagação in vitro de porongo
}

\author{
In vitro germination and propagation of bottlegourd
}

\author{
Dilson Antônio Bisognin' André Luís Lopes da Silva ${ }^{I I}$ Micheli Angélica Horback ${ }^{\mathrm{II}}$ \\ Junior Girotto $^{\text {IV }}$ Cícero João Barriquello ${ }^{\text {IV }}$
}

\section{RESUMO}

O objetivo foi desenvolver um protocolo de germinação e propagação in vitro de porongo (Lagenaria siceraria). Foram conduzidos experimentos de desinfestação $e$ germinação de sementes inteiras e sem tegumento. O meio MS suplementado de $30 \mathrm{~g} \mathrm{~L}^{-1}$ de sacarose foi utilizado para a propagação de explantes cotiledonares, ápices caulinares $e$ segmentos nodais. Sementes inteiras de porongo somente germinaram sobre papel germitest. Sementes sem tegumento, desinfestadas pela imersão em álcool $70 \%$ por $1 \mathrm{~min}$. e em solução de 3 a 4\% de hipoclorito de sódio por $10 \mathrm{~min}$, germinaram em meio de cultura contendo água destilada e $30 \mathrm{~g} \mathrm{~L}^{-1}$ de sacarose, possibilitando o estabelecimento in vitro plântulas de porongo. Explantes cotiledonares produzem brotações adventícias, e ápices caulinares e segmentos nodais crescem e enraízam em meio MS, sem a adição de reguladores de crescimento. A organogênese direta a partir de explantes cotiledonares associada à regeneração de ápices caulinares $e$ segmentos nodais facilita a propagação in vitro do porongo, o que oferece uma excelente oportunidade para explorar a cultura de tecidos, entre outras aplicações, como ferramenta auxiliar no melhoramento genético desta espécie.

Palavras-chave: Lagenaria siceraria, desinfestação, micropropagação, 6-benzilaminopurina.

\section{ABSTRACT}

The objective was to develop a protocol of 'in vitro' germination and propagation of bottlegourd (Lagenaria siceraria). Experiments of 'in vitro' disinfestation and germination were carried out with intact seeds and seeds without tegument. Cotyledonary explants, apical and nodal segments were propagated in MS medium, supplemented with $30 \mathrm{~g} \mathrm{~L}^{-1}$ of sucrose. Bottlegourd intact seeds only germinated on germitest paper. Seeds without tegument, disinfected in alcohol $70 \%$ for $1 \mathrm{~min}$. and sodium hypochlorite (3 to 4\%) for 10min., geminated in a culture medium of distilled water and $30 \mathrm{~g} \mathrm{~L}^{-1}$ of sucrose, making possible the 'in vitro' establishment of bottlegourd seedlings. Cotyledonary explants produce adventitious shoots and apical and nodal segments grow and root in MS medium without growth regulators. Direct organogenesis of cotyledonary explants and regeneration of apical and nodal segments make easy bottlegourd 'in vitro' propagation and offer a good opportunity to use tissue culture as a complementary tool for breeding and genetics or other applications.

Key words: Lagenaria siceraria, disinfection, micropropagation, 6-benzilaminopurin.

\section{INTRODUÇÃO}

O porongo (Lagenaria siceraria), pertencente à família Cucurbitaceae, é usualmente cultivado para a fabricação de cuias, constituindo uma importante fonte de renda para pequenos agricultores do Rio Grande do Sul. A cuia é o recipiente utilizado para o preparo do chimarrão, bebida originária dos nativos do sul da América Latina e ainda hoje muito apreciada (BISOGNIN \& MARCHEZAN, 1988). A excelente tolerância à baixa temperatura e a alta resistência a patógenos de solo possibilita que o porongo seja utilizado como porta-enxerto de melancia (Citrullus lanatus) e abóbora (Cucurbita pepo) em ambientes protegidos (HAN et al., 2004).

IDepartamento de Fitotecnia, Universidade Federal de Santa Maria (UFSM), 97105-900, Santa Maria, RS, Brasil. E-mail: dilsonb@smail.ufsm.br. Autor para correspondência.

IIPrograma de Pós-graduação em Agronomia, UFSM, Santa Maria, RS, Brasil.

IIIPrograma de Pós-graduação em Engenharia Florestal, UFSM, Santa Maria, RS, Brasil.

${ }^{\mathrm{IV}}$ Curso de Agronomia, UFSM, Santa Maria, RS, Brasil. 
O estabelecimento de um protocolo de propagação possibilita a realização de diversos estudos in vitro, com diversas aplicações agronômicas. Foi demonstrado em Momordica charantia que a indução in vitro de flores masculinas possibilita a produção de anteras axênicas (WANG et al., 2001). A cultura de anteras permite a obtenção de plantas haplóides androgenéticas, o que permite a obtenção de linhagens homozigóticas em uma única etapa (ANDRADE, 1998). No caso do porongo, a homozigose é de extrema importância para a fixação do caráter do formato do fruto, que é determinante para a indústria de cuia e, neste caso, para o valor comercial da produção. As populações de polinização aberta utilizadas de porongo apresentam grande diversidade genética para formato de fruto (BISOGNIN \& MARCHEZAN, 1988; BISOGNIN \& STORCK, 2000) e uma baixa percentagem de frutos industrializáveis (BISOGNIN \& MARCHEZAN, 1988).

Resultados satisfatórios têm sido obtidos com a propagação in vitro de outras espécies de cucurbitáceas, como pepino (Cucumis sativus) (SAPOUNTZAKIS \& TSAFTARIS, 1994), abóbora (PINK \& WALKEY, 1984), melancia (BARNES, 1979) e melão (Cucumis melo) (JAIN \& MORE, 1992; SPETSIDIS et al., 1996). Na cultivar "Pusa Madhuras" de melão, explantes cotiledonares podem formar calos e regenerar brotações e epicótilos com ápices e gemas axilares também regeneram brotações (JAIN \& MORE, 1992). O meio de cultura MS (MURASHIGE \& SKOOG, 1962) tem sido o mais utilizado sendo, em alguns casos, necessária a adição de reguladores de crescimento. Explantes de segmentos nodais e ápices caulinares, oriundos de brotações adventícias de mogango $(\boldsymbol{C}$. pepo), cresceram e enraizaram em meio MS sem reguladores de crescimento (SILVA et al., 2006). Já no híbrido de melão “Gália”, a adição de 2,0 $\mathrm{mg} \mathrm{L}^{-1}$ de 6benzilaminopurina (BAP) ao meio de cultura aumentou o número de brotações produzidas em gemas axilares ou a adição de $0,1 \mathrm{mg} \mathrm{L}^{-1}$ de ácido indolacético (AIA) aumentou o número de brotos produzidos. Entretanto, os brotos regenerados alongaram e enraizaram em meio de cultura sem a adição de reguladores de crescimento (SPETSIDIS et al., 1996).

O objetivo deste trabalho foi desenvolver um protocolo de germinação e propagação in vitro de porongo.

\section{MATERIAL E MÉTODOS}

Os experimentos foram conduzidos no Núcleo de Biotecnologia e Melhoramento de Plantas, Departamento de Fitotecnia, Universidade Federal de Santa Maria, Rio Grande do Sul. Todos os cultivos foram mantidos em sala de crescimento com a temperatura de $25^{\circ} \mathrm{C} \pm 3^{\circ} \mathrm{C}$ e fotoperíodo de $16 \mathrm{~h}$. A intensidade luminosa foi de aproximadamente $14,3 \mu \mathrm{E}$ $\mathrm{m}^{-2} \mathrm{~s}^{-1}$, obtida por lâmpadas brancas fluorescentes. As sementes foram inicialmente fermentadas à $25^{\circ} \mathrm{C}$ por $72 \mathrm{~h}$, na proporção de uma parte de semente e placenta para cinco partes de água (BISOGNIN et al., 1997). Para a germinação in vitro, foram utilizadas sementes inteiras e sem tegumento.

A desinfestação das sementes inteiras foi feita por imersão em álcool 70\% durante 3min, lavadas três vezes com água destilada e autoclavada, imersas novamente numa solução 2,5\% de hipoclorito de sódio $(\mathrm{NaOCl})$ por 10, 20, 30 e 40min e lavadas três vezes em água destilada e autoclavada. As sementes foram inoculadas em meio de cultura ou sobre quatro camadas de papel germitest. O meio de cultura foi constituído de água destilada e $30 \mathrm{~g} \mathrm{~L}^{-1}$ de sacarose, solidificado com $7 \mathrm{~g} \mathrm{~L}^{-1}$ de agar e $\mathrm{pH}$ ajustado para 5,7. Sementes inteiras imersas em $\mathrm{NaOCl}$ por 40min também foram inoculadas sobre papel germitest, previamente umedecido com água destilada nas proporções de 2,5; 5,$0 ; 7,5$ e 10,0 vezes a massa fresca do papel e autoclavado. A unidade experimental foi um frasco de $10 \mathrm{~mL}$, contendo $2 \mathrm{~mL}$ de meio de cultura ou as quatro camadas de papel gemitest e uma semente. Foram avaliadas as percentagens de desinfestação e germinação das sementes aos 15 dias após a inoculação. O delineamento experimental foi o inteiramente casualizado, com quatro repetições de 25 sementes.

Sementes inteiras submetidas à fermentação e embebição por $72 \mathrm{~h}$ tiveram o tegumento removido com o auxílio de pinças. Para a desinfestação, as sementes sem tegumento foram imersas em álcool 70\% durante 1min e em solução de $\mathrm{NaOCl}$ de diferentes concentrações e tempos de imersão. Após a imersão em álcool e $\mathrm{NaOCl}$, as sementes sem tegumento foram submetidas a três lavagens em água destilada e autoclavada. Foram avaliadas as concentrações de $\mathrm{NaOCl}$ de 1, 2, 3 e 4\% com os tempos de imersão de 5 e 10 min e as concentrações de $\mathrm{NaOCl}$ de 3 e $4 \%$ com os tempos de imersão de cinco, 10 e 15min. Para a germinação, as sementes foram inoculadas em meio de cultura constituído de água destilada e $30 \mathrm{~g} \mathrm{~L}^{-1}$ de sacarose, solidificado com $7 \mathrm{~g} \mathrm{~L}^{-1}$ de agar e $\mathrm{pH}$ ajustado para 5,7. A unidade experimental foi um frasco de $10 \mathrm{~mL}$, contendo $2 \mathrm{~mL}$ de meio de cultura e uma semente sem tegumento. Foram avaliadas as percentagens de desinfestação e germinação das sementes aos 15 dias após a inoculação. O delineamento experimental foi o inteiramente casualizado, com quatro repetições de 25 sementes.

Para a propagação in vitro, foram avaliados os explantes de cotilédones, ápices caulinares e 
segmentos nodais inoculados em meio MS suplementado com $30 \mathrm{~g} \mathrm{~L}^{-1}$ de sacarose, solidificado com $7 \mathrm{~g} \mathrm{~L}^{-1}$ de agar e $\mathrm{pH}$ ajustado para 5,7. Cotilédones inteiros de plântulas com 20 dias após a semeadura foram usados como explantes para a indução de brotações adventícias. Os tratamentos consistiram das concentrações de zero (testemunha), 1, 2 e $3 \mathrm{mg} \mathrm{L}^{-1}$ de BAP no meio MS. A unidade experimental foi um frasco de $10 \mathrm{~mL}$, contendo $2 \mathrm{~mL}$ de meio de cultura e um único explante. Aos 15 dias de cultivo, foram avaliados o número e a percentagem de brotações adventícias formadas por explante cotiledonar e a percentagem de explantes com raízes e o número de raízes por explante. O delineamento experimental foi o inteiramente casualizado, com quatro repetições de dez explantes.

Ápices caulinares e segmentos nodais de 1, 2 e $3 \mathrm{~cm}$ de comprimento, oriundos de plântulas com aproximadamente 30 dias, foram cultivados em meio MS. A unidade experimental foi um frasco de $10 \mathrm{~mL}$, contendo $2 \mathrm{~mL}$ de meio de cultura e um único explante. Aos sete, 14, 21 e 28 dias foram avaliados o comprimento da parte aérea e de raízes e a massa fresca total. O delineamento experimental foi o inteiramente casualizado, com quatro repetições de 20 explantes de $1 \mathrm{~cm}$ e de 10 explantes de 2 ou $3 \mathrm{~cm}$ de comprimento.

Os dados foram submetidos à análise de variância e as médias comparadas por regressão polinomial, a $5 \%$ de probabilidade de erro.

\section{RESULTADOS E DISCUSSÃO}

O aumento do tempo de imersão de sementes inteiras de porongo em solução de $\mathrm{NaOCl}$ 2,5\% não afetou a percentagem de desinfestação

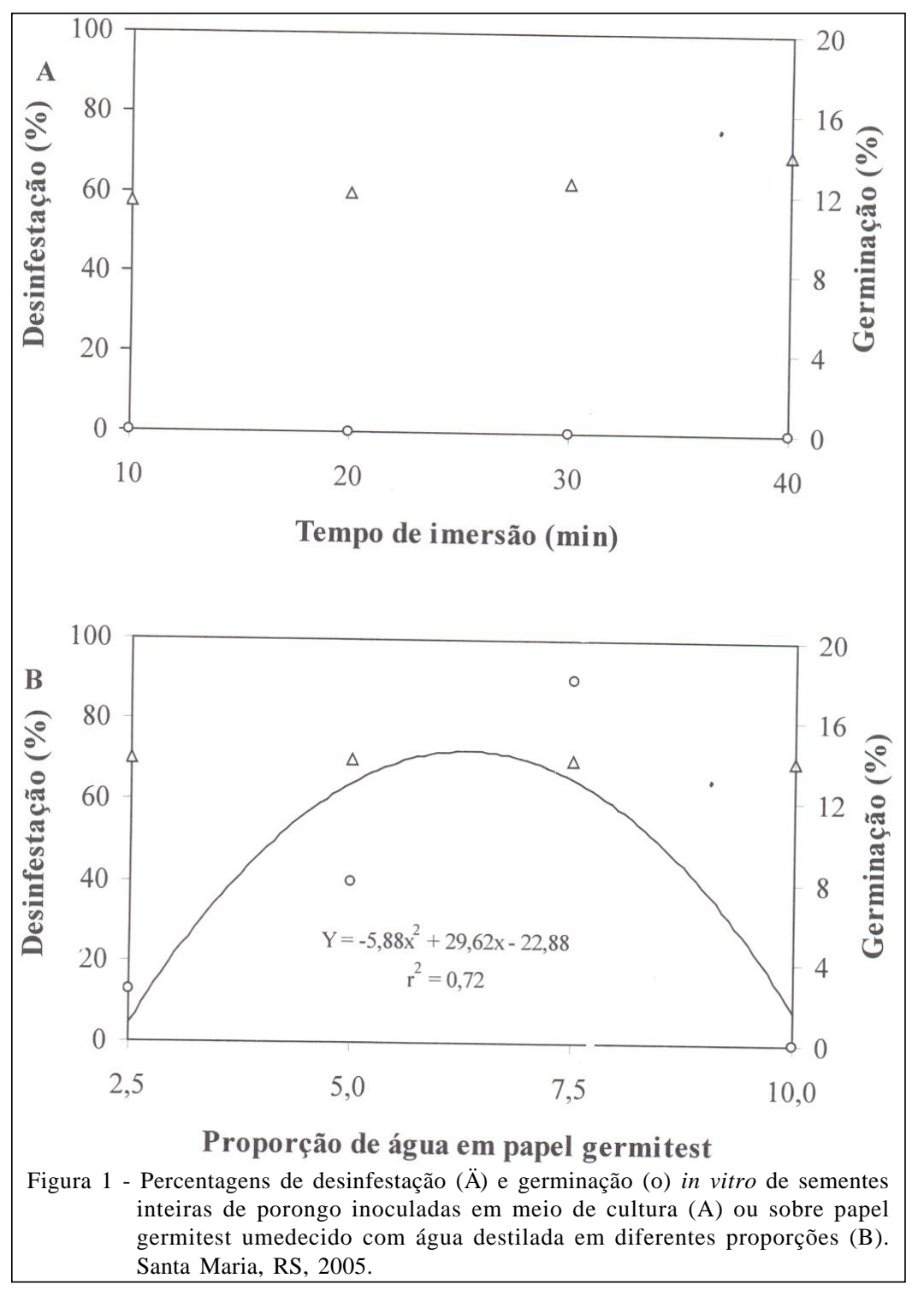

Ciência Rural, v.38, n.2, mar-abr, 2008. 
(Figura 1A). Sementes inteiras de porongo não germinaram em meio de cultura. A inoculação de sementes inteiras sobre papel germitest com diferentes proporções de água não afetou a desinfestação e aumentou a percentagem de germinação com a máxima proporção de água estimada em 6,2 vezes a massa de papel (Figura 1B).

A redução da pressão osmótica do meio de cultura poderia ser uma alternativa para a germinação de sementes inteiras de porongo. Pressão osmótica muito alta limita a absorção de água, sendo que a diluição aumenta a disponibilidade de água e reduz a oxigenação (TAIZ \& ZEIGER, 2004). No entanto, a redução da pressão osmótica do meio de cultura até a concentração de agar de $1 \mathrm{~g} \mathrm{~L}^{-1}$ não possibilitou a germinação de sementes inteiras (dados não apresentados). Sementes inteiras de porongo germinaram in vitro quando inoculadas sobre quatro camadas de papel germitest, sendo que a proporção de água e o período de cultivo têm que ser considerados para a avaliação. Aos 13 dias de cultivo, a proporção de 6,2 vezes a massa de papel foi a que apresentou os melhores resultados. A proporção de 2,5 vezes, recomendada para o teste padrão (BISOGNIN et al., 1991), é muito baixa para a germinação in vitro, pois grande parte da água fica aderida às paredes do vidro ao invés de estar em contato com as sementes. O tempo de 13 dias de cultivo para avaliar a germinação in vitro pode ser considerado elevado se comparado com oito dias do teste padrão de germinação (BISOGNIN et al., 1991).

Sementes sem tegumento germinaram em meio de cultura em todas as concentrações e tempos de imersão em $\mathrm{NaOCl}$ avaliados (Figura 2). $\mathrm{O}$ aumento das concentrações de $\mathrm{NaOCl}$ da solução entre 1 e $4 \%$ incrementaram a desinfestação das sementes, para todos os tempos de imersão. No entanto, o aumento da concentração de $\mathrm{NaOCl}$ incrementou a percentagem de germinação até a concentração de 3\% somente quando as sementes foram imersas por $10 \mathrm{~min}$. Pelo fato de que a percentagem de desinfestação foi superior na concentração de $\mathrm{NaOCl}$ de $3 \%$ em relação a de $2 \%$, somente as concentrações de 3 e $4 \%$ foram novamente avaliadas para determinar o melhor tempo de imersão. Não houve diferença significativa entre as concentrações da solução de $\mathrm{NaOCl}$ de 3 e 4\%, porém,
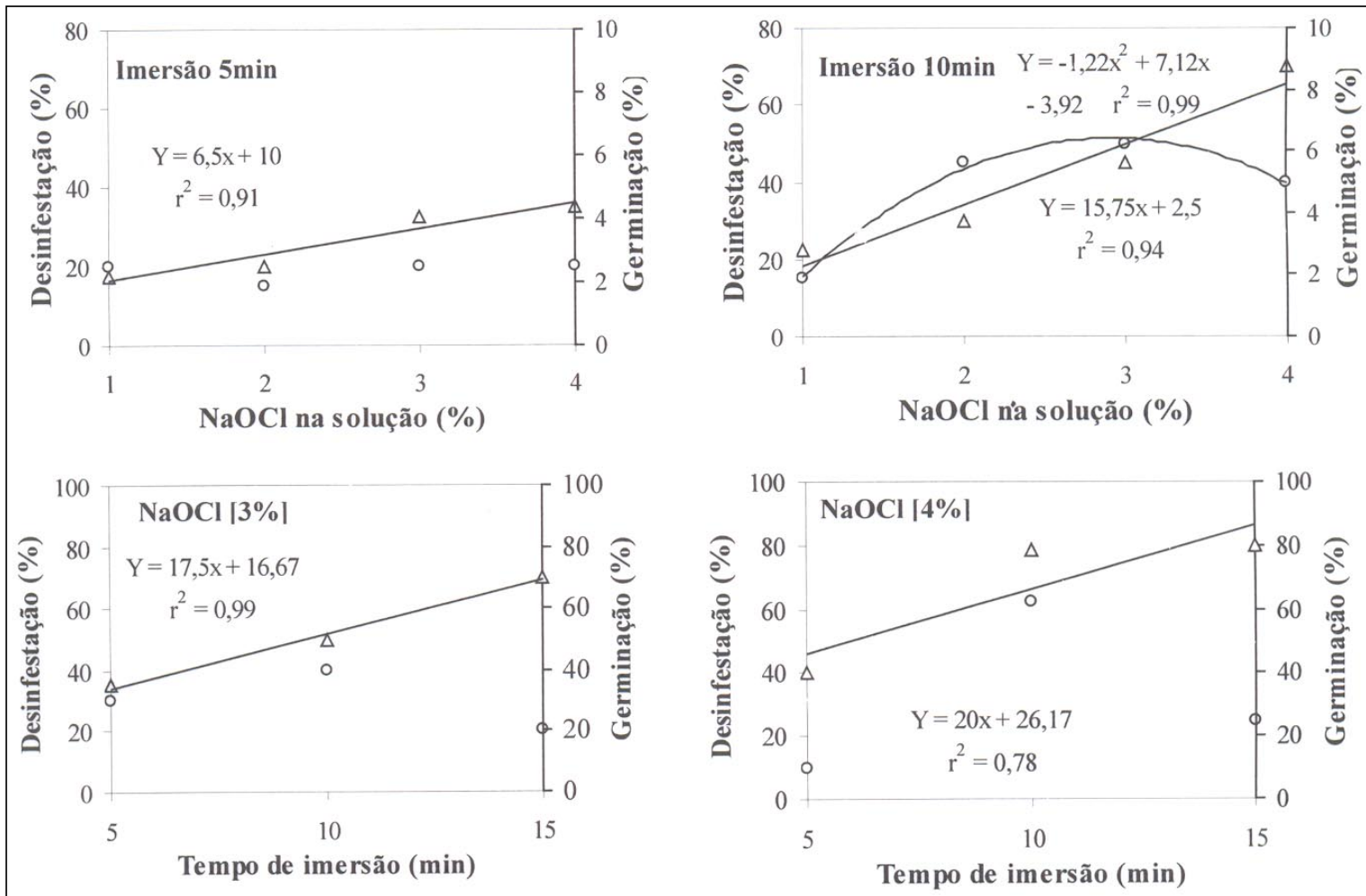

Figura 2 - Percentagens desinfestação (Ä) e germinação (o) aos 15 dias após a inoculação de sementes sem tegumento de porongo em meio de cultura após imersão em diferentes concentrações de $\mathrm{NaOCl}$ na solução e por tempos distintos. Santa Maria, RS, 2005

Ciência Rural, v.38, n.2, mar-abr, 2008. 
o tempo de imersão afetou tanto a desinfestação quando a germinação das sementes. A desinfestação das sementes sem tegumento aumentou com o tempo de imersão, porém, a imersão por 15min afetou negativamente a germinação devido ao efeito tóxico do cloro. As diferenças de germinação entre os lotes de sementes utilizados nos dois experimentos podem ser atribuídas à qualidade fisiológica devido à época de extração e ao tempo de armazenamento (BISOGNIN et al., 1999).

O tegumento da semente pode ser considerado como uma barreira para a absorção de água, pois, no momento da germinação, as sementes inteiras de porongo apresentaram 43,4\% e o embrião apenas 30,3\% de umidade (BISOGNIN et al., 1997). Nesse caso, a remoção do tegumento facilitaria a germinação in vitro das sementes em meio de cultura. A remoção mecânica do tegumento é facilitada pela fermentação, pela embebição e pelo tamanho das sementes de porongo, como também demonstrado em melancia (COMPTON, 2000). A remoção também pode facilitar a desinfestação das sementes antes da inoculação em meio de cultura devido à eliminação dos patógenos associados ao tegumento. Tanto para a desinfestação quanto para a germinação, o tempo de imersão das sementes sem tegumento foi mais importante do que a concentração da solução de $\mathrm{NaOCl}$ utilizada, pois em todas as concentração utilizadas a imersão por 10min foi superior a de $5 \mathrm{~min}$. Além disso, quando as sementes foram imersas por $5 \mathrm{~min}$, o aumento da concentração da solução de $\mathrm{NaOCl}$ até $4 \%$ não incrementou a germinação, porém, a imersão por 15min afetou negativamente a germinação. Portanto, sementes sem tegumento de porongo podem ser desinfestadas pela imersão por 1min em álcool 70\% e por 10min em solução de $\mathrm{NaOCl}$ nas concentrações de 3 a $4 \%$ para proporcionar o estabelecimento in vitro de plântulas de porongo.

Independente da concentração avaliada, a adição de BAP ao meio de cultura MS não aumentou o número de brotações adventícias e de raízes formadas. Também não houve aumento da percentagem de explantes cotiledonares com brotações adventícias e de raízes adventícias (Figura 3). Em média, 73\% dos explantes cotiledonares produziram brotações adventícias, com uma média de 1,1 brotação por explante. Esses resultados discordam, em parte, dos resultados obtidos por HAN et al. (2004) com a cultivar de porongo Partner. A regeneração de explantes cotiledonares foi de 52,4\% com uma média de 3,5 brotações por explante, obtidas somente com a adição de $3 \mathrm{mg} \mathrm{L}^{-1}$ de BAP. A adição de BAP aumentou a percentagem de explantes com brotações adventícias em algumas espécies de cucurbitáceas, como em mogango (SILVA et al., 2006), na cultivar "Má́yan” de C. pepo (ANANTHAKRISHNAN et al., 2003) e nas

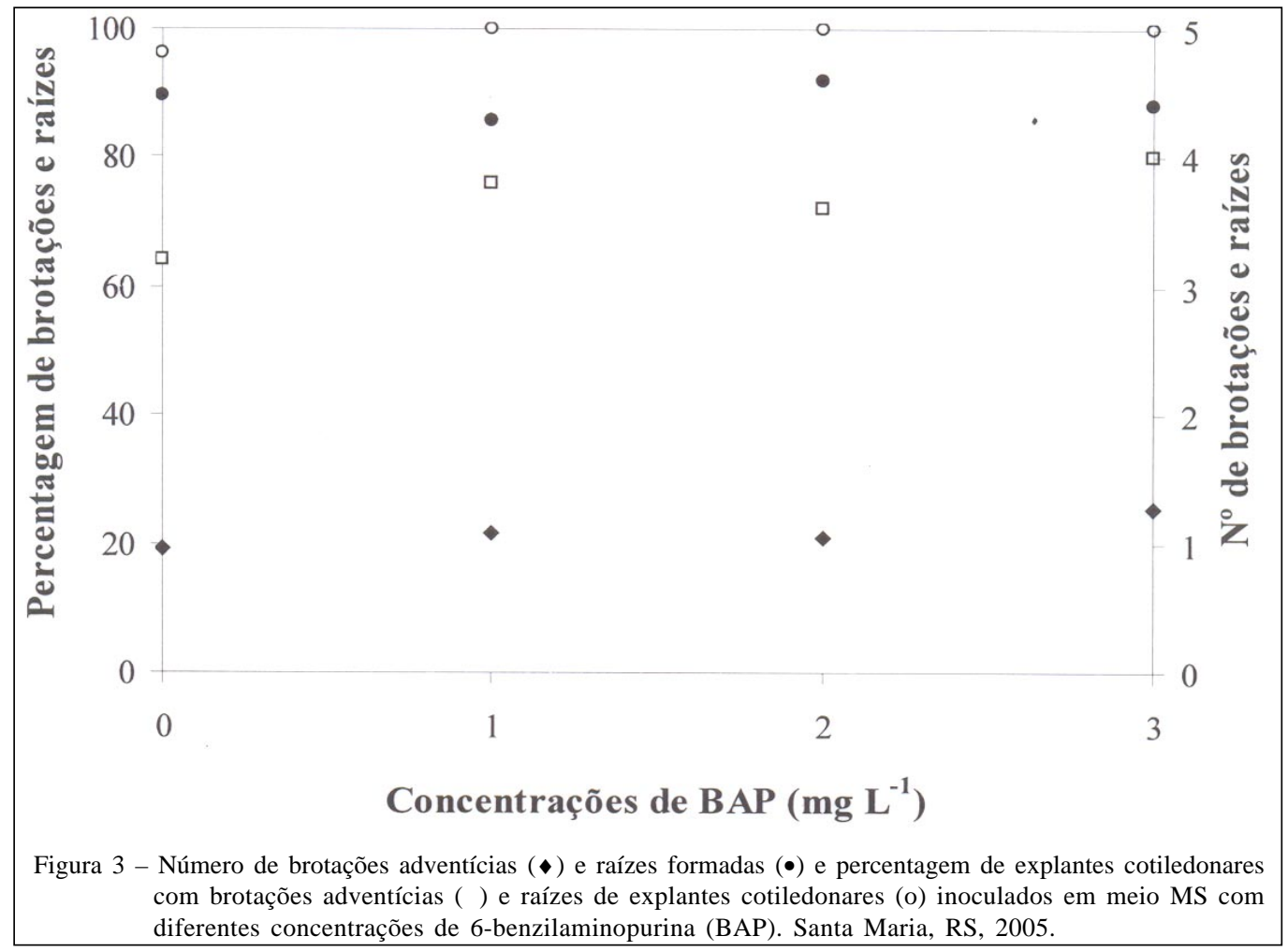

Ciência Rural, v.38, n.2, mar-abr, 2008. 
cultivares “Yellow Queen”, “Yellow King” e “AF-222” de melão (STIPP et al., 2001). Brotações adventícias também foram induzidas sem a adição de reguladores de crescimento nas cultivares "Inodorus" (STIPP et al., 2001) e "Galia” de meloeiro (SPETSIDIS et al., 1996) e "Sürme” de melancia (PIRINÇ et al., 2003). Além das diferenças genéticas entre espécies de cucurbitáceas, variações entre 21,9 a 80,7\% de explantes cotiledonares com 1,6 a 3,5 brotações adventícias por explante foram observadas em cinco cultivares de porongo (HAN et al., 2004). O fato de que $73 \%$ dos explantes cotiledonares produzem brotações adventícias e que cada explante produz em média 1,1 brotação sem adição de reguladores de crescimento ao meio MS é de extrema importância para a propagação in vitro do porongo, pois um grande número de explantes de ápices caulinares e de segmentos nodais podem ser produzidos a partir de explantes cotiledonares.

Independente do tamanho dos explantes avaliados, ápices caulinares e segmentos nodais cresceram e formaram raízes em meio MS (Figura 4). A análise dos dados aos 28 dias de cultivo mostrou
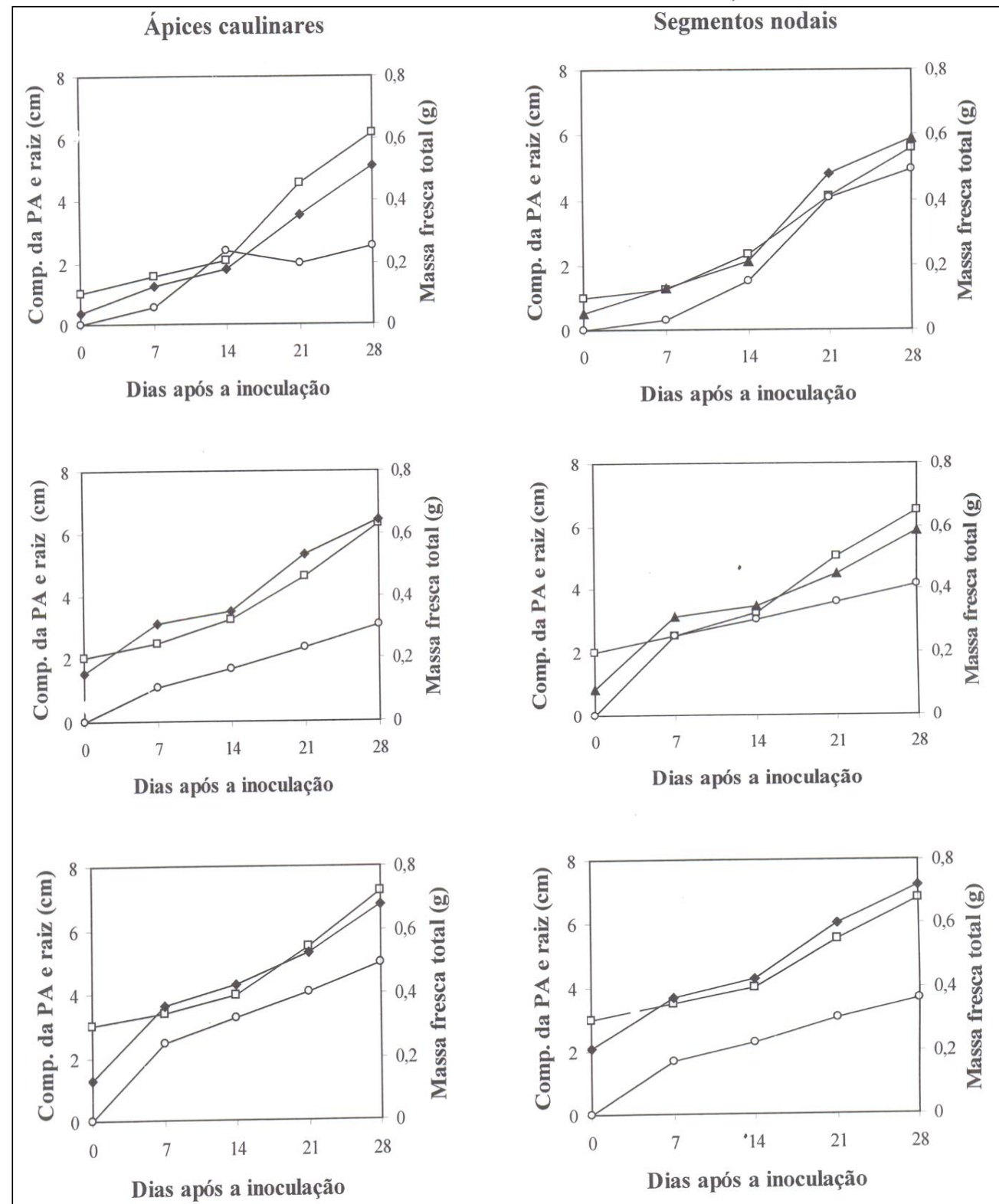

Figura 4 - Comprimento da parte aérea (PA) ( ) e de raiz (o) e massa fresca total $(\bullet)$ de explantes de ápices caulinares e segmentos nodais de $1 \mathrm{~cm}$ (acima), $2 \mathrm{~cm}$ (meio) e $3 \mathrm{~cm}$ (abaixo) inoculados em meio MS. Santa Maria, RS, 2005.

Ciência Rural, v.38, n.2, mar-abr, 2008. 
interação significativa entre tipo (ápices e segmentos nodais) e tamanho (1, 2 e 3cm) de explantes para todas as variáveis avaliadas. A massa fresca total produzida pelos explantes de segmento nodal $(0,634 \mathrm{~g})$ foi superior àquela produzida pelos ápices caulinares $(0,591 \mathrm{~g})$. Quanto maior o explante de ápices caulinares e de segmentos nodais maior foi a produção de massa fresca total da plântula. Para o comprimento da parte aérea, os explantes de ápices caulinares cresceram mais $(6,7 \mathrm{~cm})$ do que os segmentos nodais $(5,9 \mathrm{~cm})$, sendo que quanto maior o explante maior foi o crescimento em meio MS. Já o crescimento das raízes em meio MS foi similar para os explantes de segmentos nodais e ápices caulinares, sendo que o tamanho de explante foi importante somente para segmentos nodais.

O aumento do tamanho dos explantes, tanto de ápices caulinares quanto de segmentos nodais, incrementou a massa fresca total e o comprimento da parte aérea das plântulas, porém somente os segmentos nodais incrementaram o crescimento das raízes, fazendo com que os segmentos nodais produzissem maiores quantidades de massa fresca total que os ápices caulinares. Além disso, todos os tipos e tamanhos de explantes avaliados enraizaram em meio MS, o que em mogango somente foi observado em ápices caulinares maiores que 2,5cm (SILVA et al., 2006). O maior crescimento observado nos ápices caulinares pode estar associado ao nível endógeno de auxinas, responsáveis pelo alongamento e crescimento de caules (TAIZ \& ZEIGER, 2004). O percentual de enraizamento pode ser aumentado com a de adição ácido naftalenoacético (ANA) (COMPTON \& GRAY, 1993; PIRINÇ et al., 2003) ou ácido indolbutírico (AIB) (THOMAS \& SREEJESH, 2004) ao meio de cultura.

$\mathrm{O}$ porongo pode ser propagado in vitro a partir de ápices caulinares e segmentos nodais sem a adição de reguladores de crescimento ao meio de cultura. Para tal, o tamanho e o tipo de explante devem ser considerados, apesar de que tanto explantes de ápices caulinares quanto de segmentos nodais a partir de $1 \mathrm{~cm}$ de comprimento podem ser utilizados. A organogênese direta a partir de explantes cotiledonares associada à regeneração de pequenos explantes de ápices caulinares e de segmentos nodais amplia ainda mais a possibilidade de propação in vitro do porongo, o que oferece uma excelente oportunidade para explorar a cultura de tecidos como ferramenta auxiliar no melhoramento genético desta espécie.

\section{CONCLUSÕES}

A retirada do tegumento facilita a desinfestação e a germinação in vitro de sementes de porongo. A imersão de sementes sem tegumento em álcool $70 \%$ por 1 min e em solução de 3 a $4 \%$ de hipoclorito de sódio por 10min e a germinação em meio de cultura contendo água destilada e $30 \mathrm{~g} \mathrm{~L}^{-1}$ de sacarose possibilita a produção de plântulas assépticas de porongo. Explantes cotiledonares produzem brotações adventícias e ápices caulinares e segmentos nodais crescem e enraízam em meio MS sem a adição de reguladores de crescimento.

\section{AGRADECIMENTOS}

Ao Conselho Nacional de Desenvolvimento Científico e Tecnológico (CNPq), pela concessão de bolsa de Produtividade em Pesquisa para Dilson A. Bisognin e bolsas de Mestrado para André L.L. da Silva e Micheli A. Holback. À Secretaria de Educação Superior, pela concessão de bolsas do Programa de Educação Tutorial PET-Agronomia para Junior Girotto e Cícero J. Barriquello.

\section{REFERÊNCIAS}

ANANTHAKRISHNAN, G. et al. Shoot production in squash (Cucurbita pepo) by in vitro organogenesis. Plant Cell Reports, v.21, p.739-746, 2003.

ANDRADE, L.M.C.O. Otimização de técnicas de cultura de tecidos para o cafeeiro (Coffea arabica L.). 1998. 84f. Dissertação (Mestrado em Genética e Melhoramento de Plantas) - Universidade Federal de Lavras, Lavras, MG.

BARNES, L.R. In vitro propagation of watermelon. Hortscience, v.11, p.223-227, 1979.

BISOGNIN, D.A.; MARCHEZAN, E. Avaliação de algumas populações de porongo - Lagenaria siceraria (Mol.) Standl. cultivadas na região de Santa Maria, RS. Revista do Centro de Ciências Rurais, v.18, n.3-4, p.201-207, 1988.

BISOGNIN, D.A. et al. Teste de germinação em porongo Lagenaria siceraria (Mol.) Standl. Ciência Rural, v.21, n.2, p.159-167, 1991.

BISOGNIN, D.A. et al. Efeito do tamanho de fruto e do método de extração na qualidade fisiológica de sementes de porongo. Ciência Rural, v.27, p.13-19, 1997.

BISOGNIN, D.A. et al. Influência da época de extração na qualidade fisiológica de sementes de porongo. Ciência Rural, v.29, p.7-12, 1999.

BISOGNIN, D.A.; STORCK, L. Estimativa dos componentes de variância e herdabilidade para formato do fruto em porongo - Lagenaria siceraria (Mol.) Standl. Ciência Rural, v.30, n.4, p.593-597, 2000.

COMPTON, M.E. Interaction between explant size and cultivar affect shoot organogenic competence of watermelon cotyledons. HortScience, v.35, n.4, p.749-750, 2000.

HAN, J.S. et al. Efficient plant regeneration from cotyledon explants of bottlegourd (Lagenaria siceraria Standl.). Plant Cell Reports, v.23, p.291-296, 2004. 
JAIN, J.; MORE, T.A. In vitro regeneration in Cucumis melo cv. Pusa Madhuras. Cucurbit Genetics Cooperative Reports, v.15, p.62-64, 1992.

MURASHIGE, T.; SKOOG, F. A revised medium for rapid growth and bioassays with tobacco tissue cultures. Physiologia Plantarum, v.15, p.473-497, 1962.

PINK, D.A.C.; WALKEY, D.G.A. Rapid propagation of Cucurbita pepo L. by culture of meristem tips. Hortscience, v.24, p.107-114, 1984.

PIRINÇ, V. et al. Adventitious shoot organogenesis and plant regeneration from cotyledons of diploid diyarbakir watermelon (Citrullus lanatus cv. Sürme). Turkish Journal of Biology, v.27, p.101-105, 2003.

SAPOUNTZAKIS, G.; TSAFTARIS, A.S. Micropropagation of the cucumber hybrids 'Brunex' and 'Bambina'. Cucurbit Genetics Cooperative Reports, v.17, p.50-53, 1994.
SILVA, A.L.L. et al. Organogênese direta de explantes cotiledonares e regeneração de plantas de mogango. Ciência Rural, v.36, p.992-995, 2006.

SPETSIDIS, G. et al. Micropropagation of the melon hybrid 'Galia'. Cucurbit Genetics Cooperative Reports, v.19, p.63-65, 1996

STIPP, L.C.L. et al. In vitro morphogenesis of Cucumis melo var. inodorus. Plant Cell, Tissue and Organ Culture, v.65, p.81-89, 2001

TAIZ, L.; ZEIGER, E. Fisiologia vegetal. 3.ed. Porto Alegre: Artmed, 2004. 719p.

THOMAS, T.D.; SREEJESH, K.R. Callus induction and plant regeneration from cotyledonary explants of ash gourd (Benincasa hispida L.). Scientia Horticulturae, v.100, p.359-367, 2004

WANG, S. et al. In vitro flowering of bitter melon. Plant Cell Reports, v.20, p.393-397, 2001. 